\title{
SILIKÁTOVÉ ELEKTRO VODIVÉ KOMPOZITY S GRAFITOVÝM PLNIVEM
}

\author{
SILICATE CONDUCTIVE COMPOSITES WITH GRAPHITE FILLERS
}

\author{
Šimon Baránek ${ }^{* 1}$, Rostislav Drochytka ${ }^{1}$
}

*baranek.s@fce.vutbr.cz

${ }^{1}$ Fakulta stavební, Vysoké učení technické v Brně, Veveří 331/95, 60200 Brno

\begin{abstract}
Abstrakt
Elektro vodivé kompozity jsou moderní materiály, které se běžně používají v mnoha průmyslových odvětvích, jako je stavebnictví a strojírenství. Tyto materiály mohou být užitečné např́iklad jako senzory pro sledování fyzikálně mechanických změn v konstrukci, stínění bludných proudů, stínění elektromagnetického záření na operačních sálech, katodická ochrana proti vlhkosti nebo přepět'ová ochrana budov. Tématem tohoto př́spěvku je výzkum elektricky vodivých silikátových kompozitů s plnivy na bázi grafitu. V tomto výzkumu byly testovány kompozity s různým poměrem a typem grafitu a byly sledovány jejich elektro vodivé vlastnosti jako impedance, dále byly sledovány fyzikálně-mechanické vlastnosti jako pevnost v tlaku a v tahu. Bylo zjištěno že přidáním $10 \%$ hm. grafitu do směsi se sníží impedance kompozitů o $50 \%$ a pevnost v tlaku se sníží přibližně o $40 \%$.
\end{abstract}

\section{Klíčová slova}

Kompozit, grafit, elektrická vodivost, silikát, impedance

\begin{abstract}
Electroconductive composites are modern materials that are commonly used in many industries such as construction industry and machine-building industry. For example, these materials can be useful as sensors for monitoring changes in constructions, shielding stray currents from electrification networks, shielding electromagnetic radiation in operating rooms, cathodic protection against moisture or overvoltage protection of buildings. The topic of this post is the research of electrically conductive silicate composites with graphite-based fillers. In this research, composites with different ratios and types of graphite were tested and electroconductive properties such as impedance were monitored, as well as physical-mechanical properties such as strength. It was found that by adding $10 \mathrm{wt}$. graphite into the mixture reduces the impedance of the composites by $50 \%$ and the compressive strength is reduced by approximately $40 \%$.
\end{abstract}

\section{Key words}

Composite, graphite, electro conductivity, silicate, impedance

\section{1 ÚVOD}

Kompozitní materiály vytváři široké spektrum možností, kterými lze vytvářet specifické materiály na míru v závislosti na aktuálních požadavcích trhu, výzkumu a vývoje. Kompozity jsou tvořeny nejméně ze dvou a více substancí s rozdílným chemickým složením, které se liší fyzikálními a mechanickými vlastnostmi.

Ve většině případů jedna nebo více substancí tvoří tzv. plnivo, které představuje diskontinuální fázi v kompozitních materiálech. Zavedením plniv do matrice lze upravovat mnoho fyzikálních, chemických i mechanických vlastností kompozitního materiálu, jako např. objemová hmotnost, pevnost v tlaku, pevnost v tahu, objemová stálost, tepelnou a elektrickou vodivost, propustnost par a plynů, nasákavost a mnoho dalších charakteristik. Dalším přínosem plniv muže být snížení nákladů na výrobu.

Další složkou kompozitů je matrice, která má především za úkol pojit všechny komponenty v jeden celistvý materiál, tvoří kontinuální fázi materiálu a zastává funkci pojiva. Její funkcí je také udržovat požadovaný tvar a má také vliv na konečný vzhled materiálu. Matrice se podílí na mechanických a fyzikálních vlastnostech celého kompozitního materiálu. Dále má také za úkol chránit plniva případně výztuž před vnějšími vlivy, určuje tepelnou vodivost, ohnivzdornost kompozitu a jiné. Matrice bývají nejčastěji na bázi silikátových materiálů jako je např́iklad cement, na bázi polymerní například epoxidy a polyestery nebo na bázi geopolymeru [1], [2]. 
Elektro vodivé kompozity mohou být definovány jakož to kompozity s určitým obsahem plniv, které poskytují vhodné elektro vodivé vlastnosti. Pomocí elektro vodivých plniv se v materiálu vytvoří stabilní, dokonale elektricky vodivá sít', která je schopna vést elektrický proud. U pevných materiálů můžeme elektrickou vodivost rozdělit na vodivost povrchovou a vnitřní. Povrchová elektrická vodivost závisí především na vlhkosti materiálu, zatím co vnitřní vodivost souvisí se strukturou, množství a charakteru použitých vodivých plniv [1].

Jakož to elektro vodivá plniva se nejčastěji používají plniva na bázi modifikací uhlíku jako jsou např́íklad saze, grafit, uhlík, uhlíkové nanodestičky neboli grafen, uhlíkové nanotrubičky, uhlíkové trubičky, mikro silika a jiné, dále lze jako alternativu využít plniva na bázi kovů jako jsou např́klad ocelové drátky, tkaniny, nebo prášky u těchto plniv je však nižší účinnost a nejsou vhodná do silikátových kompozitů [1], [2], [3].

Impedance, analogicky jako měrný elektrický odpor (rezistivita) je vlastnost tělesa při průchodu stejnosměrného proudu, je impedance „odporem“ pro stř́davý proud. Jedná se o komplexní veličinu, která se skládá z imaginární a reálné složky. Pro přesné měření je zapotřebí přesně definovat měřené veličiny (napětí a proud).

Jakmile je v kompozitním materiálu celistvá, dokonale propojená elektro vodivá struktura, sníží se významně impedance samotného materiálu, tato hranice se nazývá perkolační práh a má za následek, že následné přidání materiálu již nemá vliv na impedanci kompozitu [4], [5], [6].

Vlastnosti silikátových kompozitů se významně mění v závislosti na typu a množství použitého plniva. $\mathrm{S}$ přidáním plniv na bázi uhlíku dochází $\mathrm{k}$ významnému poklesu fyzikálně mechanických vlastností ale také k významnému snížení impedance. Tyto vlastnosti jsou vzájemně svázány a závisí na množství plniva. Porovnáním rozlišného množství různých typů elektro vodivých plniv a jejich vlivu na fyzikálně mechanické a elektro vodivé vlastnosti se doposud nikdo nevěnoval a je poměrně opomíjené téma. $Z$ tohoto důvodu povstal podnět pro ověření interakce mezi fyzikálně mechanickými vlastnostmi a impedancí s proměnným množstvím grafitu [2].

Ve stavebnictví se tyto materiály stávají klíčovým prvkem například pro monitorování degradace konstrukcí staveb, odstínění bludných proudů z elektrifikačních sítí, odstínění elektro magnetického záření na operačních sálech, katodické ochraně před vlhkostí, ochranou budov před přepětím, odporově vyhřívané betony či stínění signálu pro vězeňské zařízení [1], [6].

\section{POPIS SOUČASNÉHO STAVU}

$\mathrm{V}$ experimentálním výzkumu, byly zkoušeny vzorky malty modifikované vodivými materiály $\mathrm{v}$ různých koncentracích byly porovnávány s neošetřenými (kontrolními) vzorky z hlediska elektrických a mechanických vlastností. Hodnocení vodivosti a pevnosti experimentálních výsledků odhalilo, že $6 \mathrm{~mm}$ nasekané uhlíkové vlákno použité v této studii je schopné poskytnout zlepšenou elektrickou vodivost ve srovnání s vodivými prášky na bázi uhlíku bez ztráty pevnosti a zpracovatelnosti. Mezi vodivými prášky na bázi uhlíku poskytuje nejhrubší grafitový prášek přijatelné zlepšení elektrické vodivosti a menší ztrátu pevnosti a zpracovatelnosti [6].

Wu a kol. zkoumali kombinaci tř́i vodivých fází (tj. ocelových vláken, grafitového prášku a uhlíkových vláken) jakož to plniva pro elektro vodivé kompozity s minimálním měrným odporem $320 \Omega \cdot \mathrm{cm}$. Ověřili také vliv disperzního činidla, vliv velikosti částic grafitu a písku na elektrický odpor kompozitu. Kompozit obsahující vodivé plniva měl zvýšenou vodivost s hodnotou odporu $10-30 \Omega \cdot \mathrm{cm}$, ale relativně nízkou pevnost v tlaku (méně než $25 \mathrm{MPa}$ ). Vysoký obsah vody požadovaný během míchání k vyrovnání absorpce vody vodivými agregáty, jako je grafit, saze a koks, vede k nízké pevnosti v tlaku. Důvodem zvýšené vodivosti je to, že když se obsah vodivých částic do určité míry zvýší, některé částice se dostanou do vzájemného kontaktu a vytvoří řetězec vnitřní sítě.

Použití grafitového prášku vyžaduje velké množství vody, takže pevnost betonu rychle klesá se zvyšujícím se dávkováním grafitového prášku. Když je dávka grafitu větší než 15 \%, zvýšení jeho vodivosti není zjevné, ale pevnost v tlaku výrazně klesá. Při dávkování grafitu větším než $20 \%$ je pevnost v tlaku menší než $2 \mathrm{MPa}$. Optimální směs obsahuje $1 \%$ objemového podílu ocelových vláken, 0,4 \% objemového podílu uhlíkových vláken a $4 \%$ obsahu grafitu, s měrným odporem $322 \Omega \cdot \mathrm{cm}$ po 28 dnech a pevností v tlaku $40 \mathrm{MPa}$ nebo vyšší [1].

Fulham-L. a kol navrhli a testovali směsi elektro vodivých betonů. Směsí obsahující malé množství grafenu vykazovaly velmi nízký měrný odpor $(177 \Omega \cdot \mathrm{cm}) \mathrm{s}$ pevností v tlaku $24 \mathrm{MPa}$. Všeobecně u směsí s nízkým poměrem w/c se zdá, že snížená kapilární pórovitost silně ovlivňuje účinek vodivosti elektrolytických iontů. Závěrem článku zmiňují důležitost vztahu mezi vodivostí, pevností a množstvím uhlíku a jeho adsorpci vody v kompozitu. Budoucí výzkum je nutný k lepšímu pochopení vnitřní vztahů elektrického odporu vodivých materiálů, vlivu poréznosti vytvořené vodou na celkové elektrické vodivosti elektro vodivých kompozitů [7]. 


\section{METODIKA}

Pro tento experiment byly navrhnuty kompozity skládající se pouze z cementu a grafitu, aby byly eliminovány negativní vlivy př́ípadně použitých elektricky nevodivých plniv.

Jako vodivé plnivo byly použity čtyři druhy průmyslově vyráběného grafitu, přičemž byly zastoupeny př́rodní i umělé grafity, hrubé i jemné frakce a jeden s vylepšenými elektro vodivými vlastnostmi pomocí povrchové úpravy (Grafit C). Nejdůležitějšími parametry použitých grafitů jsou uvedeny v Tab. 1.

Tab. 1 Vlastnosti použitých grafitů.

\begin{tabular}{ccccc}
\hline Grafit & Geneze & Typ částic & $\begin{array}{c}\text { Měrný } \\
\text { povrch } \\
{\left[\mathbf{m}^{\mathbf{2}} / \mathbf{K g}\right]}\end{array}$ & Impedance $[\mathbf{\Omega}]$ \\
\hline A & Př́rodní & Ploché vločky & 1087 & 0,98 \\
B & Pŕ́rodní & Nepravidelné vločky & 12187 & 1,45 \\
C & Př́rodní & Nepravidelné s úpravou & 19879 & 0,93 \\
D & Syntetický & Nepravidelné & 12499 & 1,19 \\
\hline
\end{tabular}

Jako pojivo pro silikátový kompozit byl použit portlandský cement CEM I 42,5 R dle EN 197-1. Jedná o běžně používaný cement označením s rychlejší nárůstem pevností než běžný cement obdobné třídy. Základní vlastnosti cementu CEM I 42,5 R dle výrobce jsou shrnuty v Tab. 2.

Tab. 2 Vlastnosti cementu.

\begin{tabular}{|c|c|c|c|}
\hline Pojivo & $\begin{array}{c}\text { Objemová hmotnost } \\
{[\mathrm{kg} / \mathrm{m} 2]}\end{array}$ & Měrný povrch $\left[\mathrm{m}^{2} / \mathrm{kg}\right]$ & Impedance [ $\Omega$ ] \\
\hline Cement CEM I 42,5 R & 3110 & 391 & $7.66 \cdot 10^{6}$ \\
\hline
\end{tabular}

Grafit byl dávkován do kompozitu hmotnostně, v podílech 4, 7, 10 a $13 \%$ z hmotnosti cementu. Tyto hodnoty byly zvoleny záměrně na základě zkušeností z odborných publikací[1], kde uvádějí že perkolační práh grafitů je okolo $10 \%$ hm. Následně vyšší dávky grafitu, než je perkolační práh by tudíž nebyly efektivní. Cement i voda byly také dávkovány hmotnostně. Byl použit vodní součinitel w/c=0.35. Složení směsí je uvedeno v Tab. 3 . Vlastnosti byly ověřeny pro každý druh a dávku grafitu na 9 zkušebních vzorcích, celkem byly vlastnosti ověřeny na 144 vzorcích.

Tab. 3 Složení směsí.

\begin{tabular}{ccc}
\hline Označení směsi & Cement (\%) & Grafit (\%) \\
\hline A 4 & 96 & 4 \\
A 7 & 93 & 7 \\
A 10 & 90 & 10 \\
A 13 & 87 & 13 \\
B 4 & 96 & 4 \\
B 7 & 93 & 7 \\
B 10 & 90 & 10 \\
B 13 & 87 & 13 \\
C 4 & 96 & 4 \\
C 7 & 93 & 7 \\
C 10 & 90 & 10 \\
C 13 & 87 & 13 \\
D 4 & 96 & 4 \\
D 7 & 93 & 7 \\
D 10 & 90 & 10 \\
D 13 & 87 & 13 \\
\hline
\end{tabular}


Na všech vstupních surovinách byly stanoveny nejdůležitější parametry, kterými byla impedance určující vodivost suroviny a měrný povrch, který vypovídá o zrnitosti a charakteru částic. Dále byl specifikován tvar zrn pomocí elektronového mikroskopu.

Měrný povrch použitých elektro vodivých plniv a cementu byl stanoven pomocí metody BET dle normy ISO 9277:1995 (E) [8].

Impedance surovin i vyrobených zkušebních těles kompozitů byla stanovena pomocí měŕícího prrístroje GW Instek LCR-6020 při napětí $1.0 \mathrm{kHz}$. Impedance surovin byla měřena pomocí př́ípravku s elektrodami vytištěném na 3D tiskárně, který je na Obr. 1-A. Impedance kompozitu byla stanovena na vzorcích 40x40x160 mm viz. Obr. 1 -C, do kterých jsou zabudovány měděné elektrody viz. Obr. 1 -B ve vzdálenosti 120 mm.
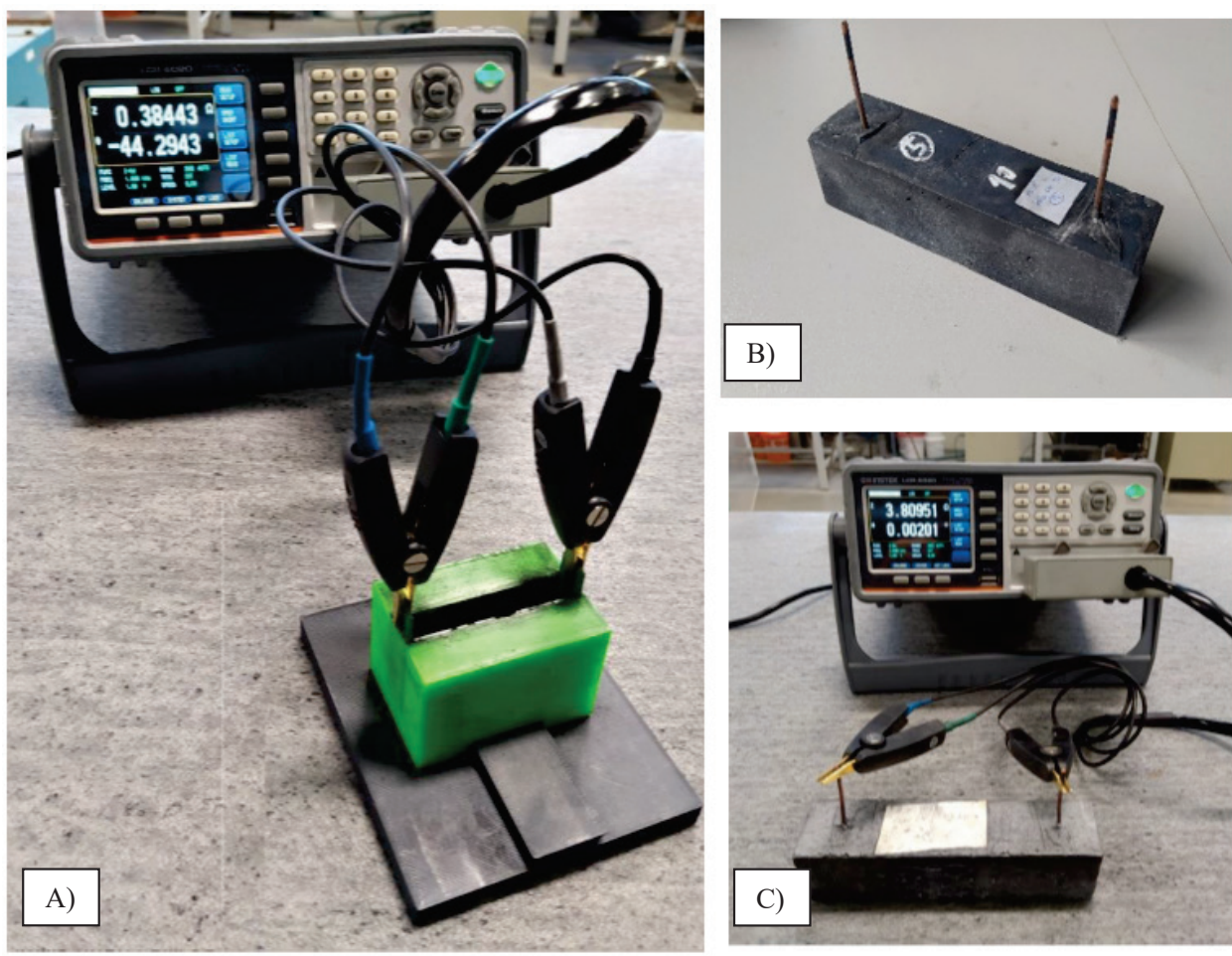

Obr. 1 A) Měřící přístroj GW Instek LCR-6020 při měření impedance surového grafitu, B) zkušební těleso se zabudovanými elektrodami, C) měření impedance zkušebních těles.

Fyzikálně mechanické vlastnosti kompozitů byly stanoveny po 28 dnech zrání v normovém prostředí na zkušebních tělesech 40 × 40 x $160 \mathrm{~mm}$. Na vzorcích byla stanovena pevnost v tahu za ohybu pomocí tříbodového ohybu, dle ČSN EN 12390-5. Na zlomcích těles ze stanovení pevnosti v tahu za ohybu byla stanovena pevnost v tlaku v souladu s ČSN EN 12390-4 [9], [10].

\section{VÝSLEDKY}

Výsledky měření impedance a stanovení pevnosti v tlaku a pevnosti v tahu za ohybu po 28 mi dnech u kompozitů s odlišným množstvím a typem grafitu jsou vyhodnoceny v následujících grafech. 


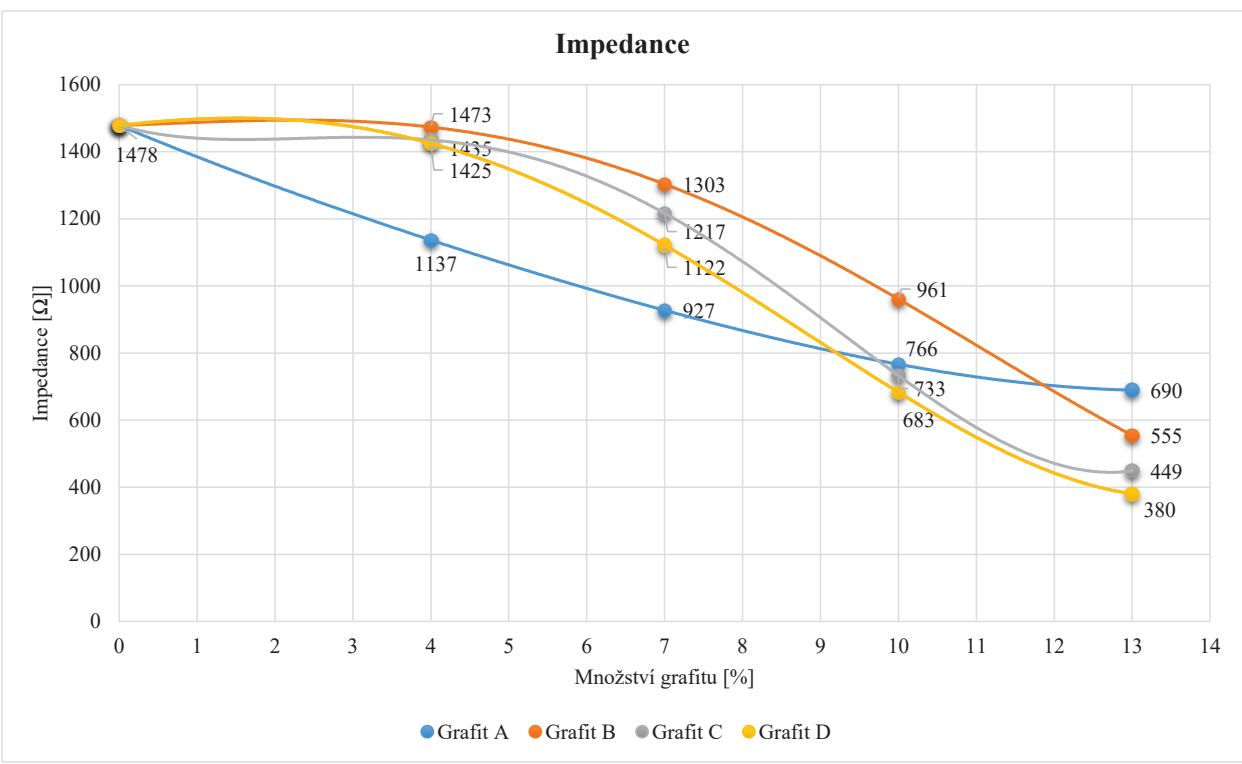

Obr. 2 Vliv množství a typu grafitu na impedanci kompozitu.

S přidáním grafitů do kompozitu se významně snižuje jeho impedance. Nejvyšší pokles byl zaznamenán při dávce $13 \%$ hm., avšak dle trendu zřejmě nebylo dosaženo prahu perkolace, který je udáván okolo $10 \%$ hm. Impedance byla snížena při dávkách 4, 7, 10 a 13 \% průměrně o 8, 22, 47 a 65 \%. Naměřené hodnoty jsou graficky zpracovány v Obr. 2.

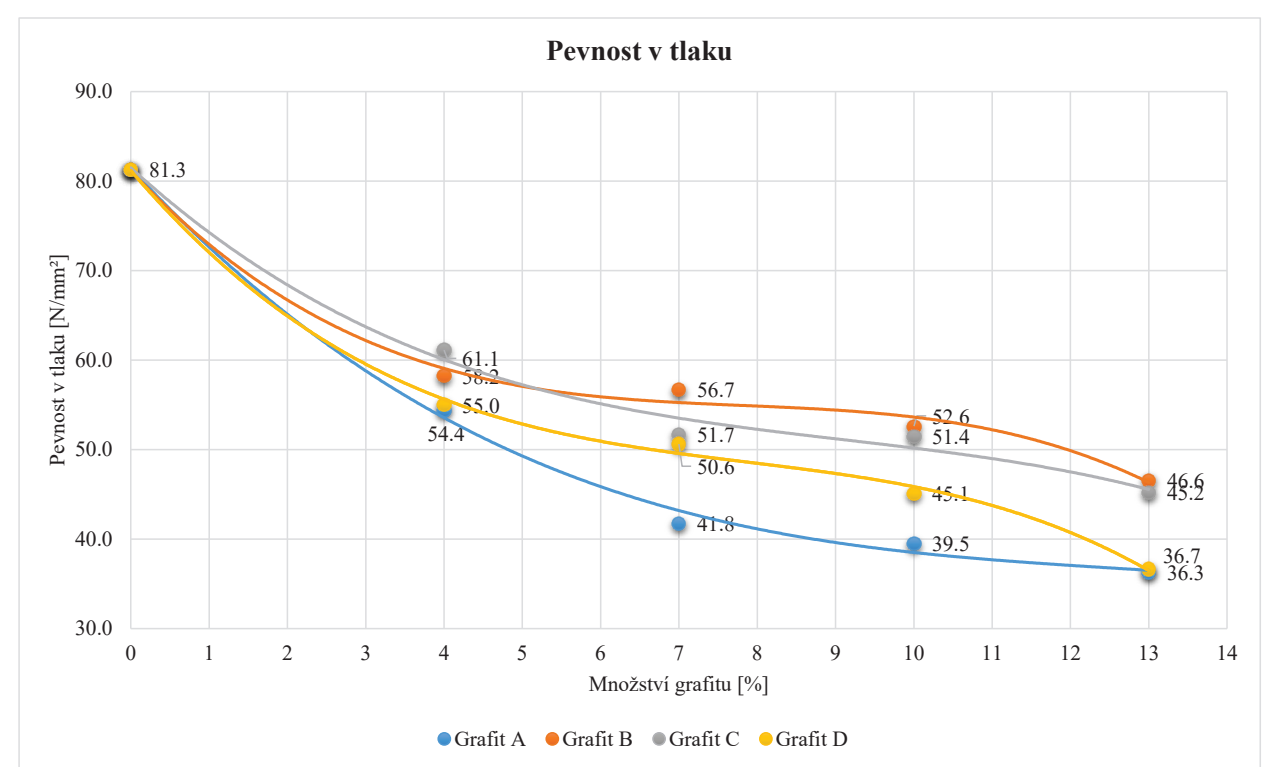

Obr. 3 Vliv množství a typu grafitu na pevnost v tlaku kompozitu. 


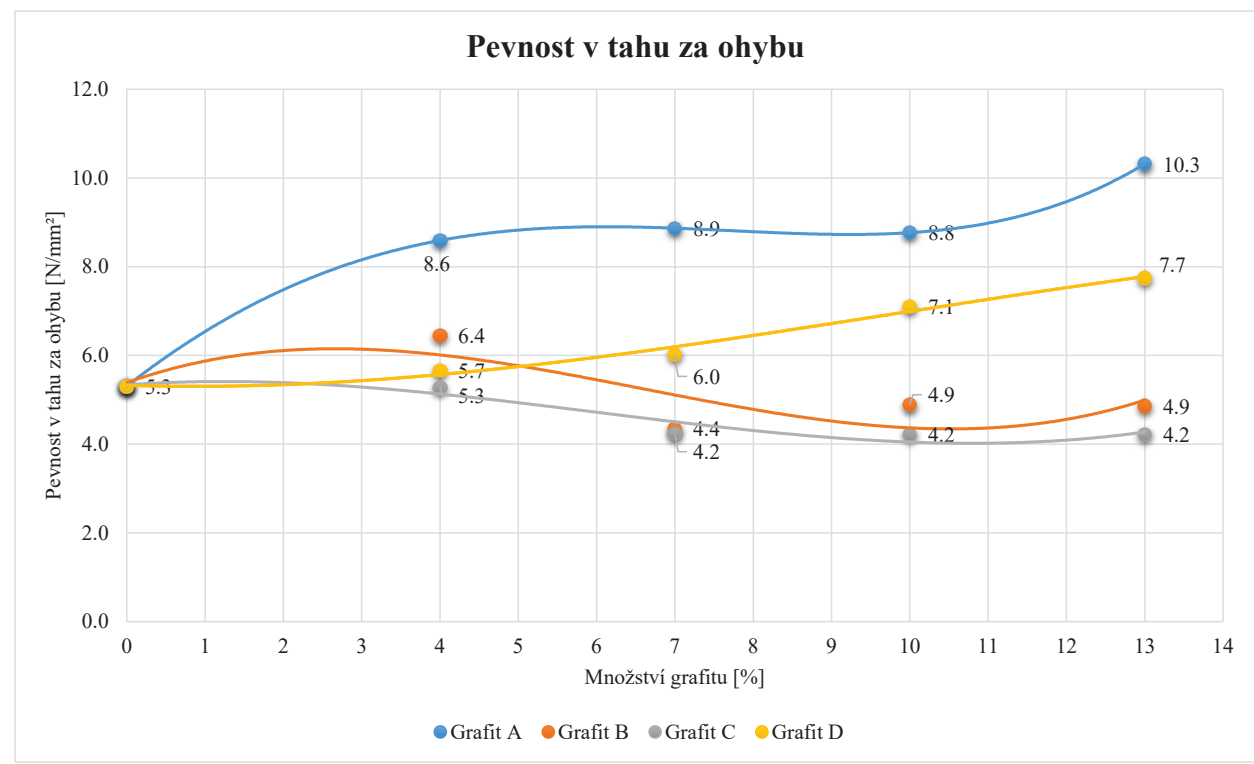

Obr. 4 Vliv množství a typu grafitu na pevnost v tahu za ohybu kompozitu.

Fyzikálně mechanické vlastnosti uvedené na Obr. 3 a Obr. 4, jsou také ovlivněny přidáním grafitu do kompozitu, již při nízkých dávkách grafitového prášku dochází k významnému poklesu pevností v tlaku, pevnost v tahu za ohybu se zlepšila při použití hrubého typu grafitu (Grafit A) a (Grafit D) se střední zrnitostí a nepravidelným typem částic, toto zlepšení je do jisté míry ovlivněno hutněním a nízkou absorpcí Grafitu A.

\section{DISKUZE}

Z výše uvedených výsledků je zřejmé že přidání grafitu ovlivňuje především elektrickou vodivost a pevnost v tlaku kompozitu, tyto hodnoty poměrně klesají úměrně se zvyšující se dávkou plniva.

Bylo potvrzeno že hrubší typy grafitu vykazují nižší účinnost oproti grafitům jemného typu, ale také umožňují docílit vyšších pevností díky nižší adsorpci vody. Hrubý typ grafitu vykazuje lepší efektivitu v nižších dávkách.

U pevnosti v tlaku byl zaznamenán významný pokles již při přidání $4 \%$ grafitu, kdy klesla pevnost v průměru o $30 \%$. Při dávce $7 \%$ klesla pevnost v tlaku o $38 \%$, při $10 \%$ grafitu klesla pevnost o $42 \%$ a při dávce $13 \%$ grafitu klesla pevnost v tlaku o $50 \%$. Ukázalo se, že oproti dřivějším publikacím týkající se tohoto tématu má do značné míry na pevnosti i elektro vodivé vlastnosti také zřejmě vliv použitých surovin, jelikož se i při vyšších dávkách grafitu (nad $10 \%$ ) dokázaly zachovat poměrně dobré mechanické vlastnosti (pevnost v tlaku nad 30 N/mm²).

\section{ZÁV̌̌R}

Cílem tohoto příspěvku bylo sledování elektro vodivých a fyzikálně mechanických vlastností a jejich interakcí v silikátových kompozitech s plnivem na bázi uhlíku. Byly otestovány různé dávky a typy grafitu a zároveň byla sledována impedance, pevnost v tlaku a pevnost v tahu za ohybu kompozitů.

Zavedením vhodných typů grafitů do silikátového kompozitu lze významně ovlivňovat jeho elektro vodivé ale také fyzikálně mechanické vlastnosti. Grafit, jakož to plnivo je účinným nástrojem pro snížení impedance. Ta se sníží při dávce grafitu okolo $10 \%$ hm. přibližně o $50 \%$, přičemž pevnost v tlaku klesne přibližně o $40 \%$. Hodnoty těchto vlastností klesají souměrně dle trendů s každým přidaným procentem plniva. Pevnost v tahu za ohybu je ovlivněna zejména zrnitostí plniva, přičemž hrubší typy grafitu s vločkovitým typem částic mají vyšší schopnost přenášet síly vyvozené na materiál za tím co jemné typy grafitů pevnost v tahu za ohybu snižují.

Bylo prokázáno, že syntetický grafit a grafity s nepravidelnými a velmi jemnými částicemi jsou efektivnější pro docílení nižších hodnot impedance. To je dáno větším měrným povrchem částic, a tedy vyšší pravděpodobnosti styku nepravidelných ploch zrn v kompozitní matrici. Rozdílná impedance samotných grafitů jakož to suroviny nemá prímý vliv na impedanci celého kompozitu. Lze říct že impedance kompozitu se odvíjí především od vhodné velikosti, tvaru částic a efektivního množství použitého vodivého plniva. 
Pro budoucí výzkum díky významnému vlivu vodního součinitele na mikrostrukturu kapilárního systému, který následně ovlivňuje elektrickou vodivost iontů v kompozitu by bylo vhodné experimentálně vyzkoušet vliv vodního součinitele, př́ípadně otestovat vliv plastifikačních přísad.

\section{Poděkování}

Tento článek je vytvořen v rámci specifického výzkumného projekt č. FAST-J-21-7491 „Studium struktury elektricky vodivých silikátových kompozitů s obsahem plniv na bázi uhlíku“.

\section{Použité zdroje}

[1] WU, Jianmin, Jianguo LIU a Fei YANG. Three-phase composite conductive concrete for pavement deicing. ELSEVIER. Construction and Building Materials [online]. 2015, 30 January 2015, 2015(75), 129-135 [cit. 2020-10-25]. ISSN 0950-0618.

[2] TERASHITA, Keijiro, Tetsuya TANAKA, Kiyohiko NISHIMURA a Kei MIYANAMI. Continuous kneading for electrically conductive composite materials and evaluation of filler dispersion state. Bulletin of the University of Osaka Prefecture, Series A Engineering and Natural Sciences. 1993, 42(1), 51-67.

[3] RHEE, I., J.S. LEE, Y.A. KIM, J.H. KIM a J.H. KIM. Electrically conductive cement mortar: Incorporating rice husk-derived high-surface-area graphene: Incorporating rice husk-derived highsurface-area graphene. Construction and Building Materials. 2016, 125, 632-642.

[4] XIE, Ping, Ping GU a J. J. BEAUDOIN. Electrical percolation phenomena in cement composites containing conductive fibres. Journal of Materials Science. 1996, 31(15), 4093-4097. ISSN 15734803.

[5] KIM, G.M., S.M. PARK, G.U. RYU a H.K. LEE. Electrical characteristics of hierarchical conductive pathways in cementitious composites incorporating CNT and carbon fiber. Construction and Building Materials [online]. 15 June 2017n. 1., 2017(82), 165-175 [cit. 2020-10-25].

[6] GOPALAKRISHNAN, K., H. CEYLAN, S. KIM, S. YANG a H. ABDUALLA. Electrically conductive mortar characterization for self-heating airfield concrete pavement mix design. International Journal of Pavement Research and Technology. 2015, 8(5), 315-324.

[7] FULHAM-LEBRASSEUR, R., L. SORELLI a D. CONCIATORI. Development of electrically conductive concrete and mortars with hybrid conductive inclusions. Construction and Building Materials. 2020, 237.

[8] ISO 9257:1995(E) Určování specifické plochy povrchu pevných látek adsorpcí plynu použitím BET metody

[9] ČSN EN 12390-5. Zkoušení ztvrdlého betonu - Část 5: Pevnost v tahu ohybem zkušebních těles. 2009.

[10] ČSN EN 12390-4. Zkoušení ztvrdlého betonu - Část 4: Pevnost v tlaku - Požadavky na zkušební lisy. 2001. 